\title{
TEKNOLOGI KLONING DALAM PERSPEKTIF PAI MATERI FIQH
}

\author{
Al Qudus Nofiandri Eko Sucipto Dwijo \\ (Dosen FTK UIN Sunan Ampel)
}

\begin{abstract}
Abstrak:
Tulisan ini berusaha memotret teknologi kloning dalam perspektif PAI materi Fiqh. Ketika ditinjau dari sisi hifzh aldin (memelihara agama), kloning manusia tidak membawa dampak negatif terhadap keberadaan agama. Ditinjau dari sisi hifzh al-nafs (memelihara jiwa), kloning tidak menghilangkan jiwa bahkan justru melahirkan jiwa yang baru. Dilihat dari sisi hifzh al-'aql (memelihara akal), kloning juga tidak mengancam eksistensi akal, bahkan keberhasilan Kloning yang sempurna dapat membuat manusia mempunyai akal cerdas. Jika dilihat dari sisi hifzh al-nasl (memelihara keturunan), kloning manusia dipertanyakan. Dalam pandangan Islam, masalah keturunan merupakan sesuatu yang sangat essensial, karena keturunan mempunyai hubungan erat dengan hukum yang lain seperti pernikahan, warisan, muhrim, dan sebagainya. Apabila ditinjau dari sisi hifzh al-mal (memelihara harta), akan terkait dengan mashlahat dan mafsadat yang diperoleh dari usaha pengkloningan. Andaikata Kloning terhadap manusia hanya akan menghambur-hamburkan harta, tanpa adanya keseimbangan dengan manfaat yang diperoleh, maka kloning menjadi terlarang. Dengan penerapan kloning, kemapanan dan keluhuran cita-cita sebuah perkawinan dalam Islam akan terusik. Boleh jadi, di masa yang akan datang manusia tidak membutuhkan perkawinan untuk mendapatkan keturunan. Seks hanya diperlukan untuk melampiaskan hawa nafsu birahi terhadap lawan jenis tanpa mempertimbangkan akibat dan tanggung jawab dari
\end{abstract}


Al Qudus Nofiandri Eko Sucipto Dwijo

hubungan seksualitas tersebut. Dengan demikian, kemafsadatan yang ditimbulkan akibat kloning manusia lebih besar daripada kemanfataannya. Oleh karena itu, kloning manusia diharamkan dalam ajaran Islam.

Kata Kunci: Kloning Manusia dan PAI Materi Fiqh

\section{A. Pendahuluan}

Perkembangan ilmu pengetahuan dan teknologi dewasa ini telah mencapai titik kulminasi. Bersamaan dengan itu, kebutuhan masyarakat sebagai subjek dan sekaligus objek dari ilmu pengetahuan dan teknologi kian meningkat. Karena itu, berbagai problem yang dihadapi masyarakat yang tidak terselesaikan melalui sistem tradisional, dilakukan upaya lain, misalnya, ingin dapat keturunan dilakukan melalui sistem modern seperti kloning.

Kenyataan tersebut berimplikasi pada eksistensi hukum, dalam hal ini hukum Islam dihadapkan dengan realitas yang aktual. Akan tetapi, nuansa universalitas dan fleksibilitas secara fungsional melekat pada hukum Islam sehingga problem yang dihadapi umat masa lalu, masa kini, dan masa mendatang pasti dapat dideteksi dan ditemukan solusinya.

Penemuan-penemuan baru hasil pengembangan ilmu pengetahuan dan teknologi, sebenarnya terjadi di sepanjang sejarah. Ada yang mendapat sambutan baik masyarakat tanpa menimbulkan kontroversi yang berarti, namun juga tidak jarang pula yang mendapat pertentangan keras tetapi belakangan mereka bisa menerima ataupun ada juga yang ditolak sama sekali.

Penemuan-penemuan baru tersebut, biasanya akan membawa dampak-dampak perubahan yang spektakuler bagi 
peradaban umat manusia. Baik itu bersifat material maupun non-material seperti sikap dan pandangan hidup itu sendiri. Gejala-gejala seperti itu dapat diamati sepanjang sejarah umat manusia. Diantara temuan-temuan itu adalah penemuan di bidang bioteknologi seperti kloning. Islam sangat menghargai kemajuan ilmu pengetahuan dan teknologi, termasuk teknologi kloning. Bahkan lebih jauh manusia diperintahkan untuk memikirkan, menggali dan mengupayakan seoptimal mungkin tentang semua ciptaan Tuhan. Bagi manusia sendiri, memikirkan dan memahami bagaimana ia diciptakan amatlah dianjurkan.

Hal ini tercermin dalam firman Tuhan dalam surat Al'Alaq: 1-5 yang merupakan ayat pertama al-Quran yang diturunkan kepada Nabi Muhammad Saw; "Bacalah dengan (menyebut) nama Tuhanmu yang menciptakan. Dia telah menciptakan manusia dari segumpal darah. Bacalah dan Tuhanmu Maha Pemurah. Yang mengajarkan manusia dengan perantara kalam. Dia mengajarkan kepada manusia apa yang tidak diketahuinya".

Kewajiban membaca, meneliti, mengkaji dan seterusnya menjadi intens dengan ajaran Islam. Secara eksplisit ayat diatas juga mengisyaratkan bahwa segala penguasaan ilmu dan teknologi merupakan ilmu Tuhan, dan dari ayat itu pulalah dapat dipahami bahwa keberhasilan sebuah penelitian semacam kloning misalnya atas restu dari Tuhan. ${ }^{1}$

Tidak ada seorang pun di dunia ini yang bisa melarang berjalannya penelitian dengan menggunakan embrio manusia. Kecintaan yang berlebih-lebihan pada ilmu dunia ternyata telah membuat manusia lupa pada tujuan utama untuk belajar ataupun mengadakan penelitian. Islam tidak melarang manusia

\footnotetext{
${ }^{1}$ http://abraham4544.wordpress.com/umum/hukum-kloning-dalamperspektif-agama-islam/ (Akses pada 15 Oktober 2014).
} 
untuk mengadakan berbagai penyelidikan mengenai ciptaan Allah Swt. Agama Islam bahkan mendorong agar manusia melakukannya dalam rangka mengenal lebih dekat terhadap Allah Swt, mengetahui kebesaran-Nya, sehingga menjadikan manusia lebih tunduk dan taat dalam mematuhi perintah-Nya.

\section{B. Kloning Manusia dalam Perspektif Fiqh}

Praktik kloning memiliki tiga bentuk cara: 1. Bibit yang diambil adalah dari bibit sel telur yang sudah tidak berfungsi lagi (mandul), kemudian diambil bibit perempuan lain dan dicampurkan sesuai dengan proses tertentu; 2. Bibit sel telur yang diambil adalah bibit wanita itu sendiri; 3. Bibit diambil dari laki-laki dan perempuan yang masih produktif. Setelah sempurna praktik penyuburan sel telur dengan sperma lewat langkah-langkah teori ilmiah, maka tinggal menunggu hasil dari teori ini.

Dari beragam pertimbangan mungkin pertimbangan hukum akan secara tegas memberikan putusan, khususnya dari para ulama' fiqh yang menolak mengenai praktik kloning manusia. Larangan ini muncul karena alasan adanya kekhawatiran tingginya frekuensi mutasi pada gen produk kloning sehingga akan menimbulkan efek buruk pada kemudian hari dari segi pembiayaan yang sangat mahal dan juga dari sudut pandang ushul fiqh bahwa jika sesuatu itu lebih banyak madharat-nya daripada manfaatnya maka sesuatu itu perlu ditolak.

Dalam terminologi fiqh, kloning manusia memunculkan berbagai pertanyaan antara lain: bolehkah kloning dilakukan dengan menggunakan DNA suami yang sah? Dapatkah perempuan mengkloning dengan DNA sendiri? Bolehkah sepasang suami istri menggunakan DNA anak kandungnya sendiri? Apakah seseorang berhak dan darimana hak itu 
diperoleh untuk menggunakan DNA sendiri? Bagaimana jika salah seorang di antara suami istri tidak setuju dengan proses kloning itu? Dalam kloning, seseorang bisa saja punya anak tanpa istri atau suami, tinggal memesan sel telur yang telah direkayasa dalam bank sel telur lalu dititipkan ke rahim seorang perempuan hingga melahirkan.

Jika demikian, bagaimana jadinya institusi perkawinan yang sudah diatur sedemikian rupa dalam undang-undang hukum Islam dan hukum positif? Bagaimanakah dengan konsep-konsep Islam seperti muhrim, wali, nasab, waris dan kekerabatan? Bukankah keluarga dibentuk tidak hanya untuk melahirkan keturunan, tetapi juga menghasilkan kondisi psikologis yang nyaman dan damai serta bermartabat?2

Dari beberapa aspek, teknologi kloning memiliki manfaat yang sangat sedikit, namun memiliki dampat negatif yang sangat beragam. ${ }^{3}$ Seperti dalam bahasa kaidah fiqh dinyatakan: "Menghindari madhlarat (bahaya) harus didahulukan atas mencari kebaikan atau maslahah". Kaidah ini menjelaskan bahwa suatu perkara yang terlihat adanya manfaat atau maslahah, namun disana juga terdapat kemafsadat-an (kerusakan), haruslah didahulukan menghilangkan mafsadah-nya. Sebab ke-mafsadahan-nya dapat meluas dan menjalar kemana-mana sehingga akan mengakibatkan kerusakan yang lebih besar. ${ }^{4}$

Praktik yang pertama, hukumnya adalah haram dengan alasan mencampurkan bibit laki-laki dengan sel telur wanita lain untuk bisa hamil dan melahirkan anak. Dalam al-Qur'an Allah Swt berfirman:

\footnotetext{
${ }^{2}$ Nasaruddin Umar, "Pandangan Islam terhadap Kolning Manusia", Kompas (Jakarta: 21 April 2002).

http://fun-bio.blogspot.com/2011/04/kloning-manusia-dalam-perspektifislam.html (Akses pada 15 Oktober 2014).

${ }^{4}$ Imam Musbikin, Qowa'id al-Fiqhiyah (Jakarta: Raja Grafindo Persada, 2001).
} 
Al Qudus Nofiandri Eko Sucipto Dwijo

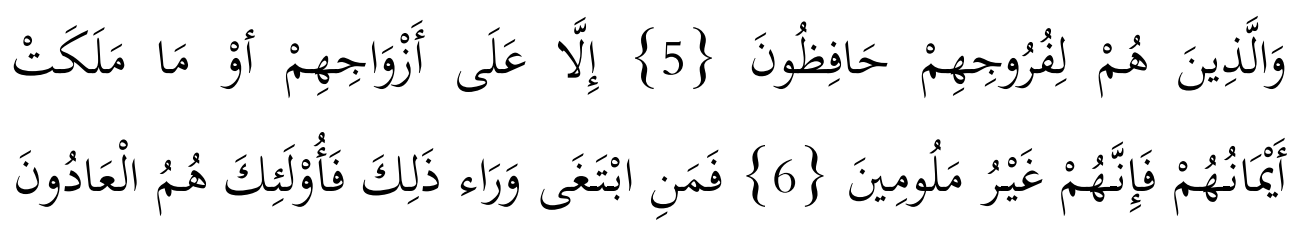

"Dan orang-orang yang menjaga kemaluannya, kecuali terhadap istri-isteri mereka atau budak yang mereka miliki, maka sesungguhnya mereka dalam hal ini tidak tercela. Barang siapa yang mencari di balik itu, maka mereka itulah orang-orang yang melampaui batas."

Ayat di atas memerintahkan untuk memelihara kemaluan laki-laki maupun wanita dari yang haram. Wanita tidak boleh berhubungan dengan laki-laki, kecuali suami atau budak beliannya begitu juga wanita dengan wanita (lesbian) atau laki-laki dengan laki-laki (homoseksual). Sebab ini adalah termasuk pebuatan zina yang akan mengakibatkan kaburnya nasab atau keturunan.

Bentuk praktik yang kedua, yaitu mengambil bibit perempuan itu sendiri lalu dicampur dengan sel telurnya, hukumnya adalah haram juga. Adapun dalil yang menunjukan keharamannya, antara lain Hadits Rasulullah yang maksudnya: "Apabila laki-laki bersetubuh dengan laki-laki (homoseksual) adalah zina dan apabila wanita bersetubuh dengan wanita (lesbian) adalah zina".

Bentuk praktik yang ketiga, yaitu melahirkan lewat proses mengambil bibit dari sperma laki-laki lalu dicampurkan kedalam sel telur wanita, hukumnya ialah sebagi berikut:

1. Apabila bibit ini diambil dari seekor hewan, maka hukumnya adalah haram. Sebab ini menyia-nyiakan ciptaan Allah Swt. Dan diragukan akan lahir manusia, karena bisa jadi yang lahir nantinya makhluk selain manusia. 
2. Apabila bibit diambil bukan dari suaminya, maka hukumnya juga haram. Sebab syariat Islam mengharamkan wanita melahirkan anak yang bukan hasil dari suaminya.

3. Apabila bibit diambil dari suaminya sendiri, maka hukumnya adalah tawaqquf. Tawaqquf adalah istilah yang sering muncul dalam ilmu fiqih, karena dalil-dalil saling bertentangan satu dengan lainnya atau tidak mungkin memilih salah satu diantara pendapat yang berbeda. Maka tidak menghalalkan dan tidak mengharamkan melahirkan anak tanpa hubungan suami istri (jima'), sebab belum dapat memastikan sifat dan ciri-ciri anak yang akan lahir lewat proses ini. Apakah seperti manusia biasa yang sehat jasmani dan ruhani atau malah sebaliknya.

Apabila seorang suami impoten, baik disebabkan penyakit atau yang lain, sehingga tidak mungkin melakukan hubungan suami istri dengan baik, sedang ia sangat merindukan seorang anak, apakah praktik ini dibolehkan baginya menurut hukum Islam? Apabila sudah dapat dipastikan akan lahir seorang manusia yang sempurna, maka praktik ini boleh dilakukan untuk pasangan suami istri, dengan tiga ketentuan:

1. Bayi yang dilahirkan sempurna ruhani dan jasmaninya dan tidak mengakibatkan dampak negatif terhadap dirinya, keluarganya dan masyarakat sekitarnya.

2. Seorang suami tersebut betul-betul impoten, tidak mungkin sama sekali untuk mendapatkan anak, kecuali dengan praktik ini.

3. Praktik ini tidak boleh dilakukan lebih dari satu kali atau lebih dari seorang anak.

Sementara itu, kloning terhadap tumbuh-tumbuhan atau hewan asalkan memiliki daya guna (bermanfaat) bagi 
kehidupan manusia maka hukumnya mubah/ halal. Hal ini didasarkan pada prinsip bahwa segala sesuatu yang ada di dunia ini diciptakan untuk kesejahteraan manusia. Dalilnya: Q.S. Al-Baqoroh: 29, yang artinya;

"Dia-lah Allah, yang menjadikan segala yang ada di bumi untuk kamu dan Dia berkehendak (menciptakan) langit, lalu dijadikan-Nya tujuh langit, dan Dia Maha mengetahui segala sesuatu." 5

Berdasarkan pengalaman yang telah dilakukan beberapa ulama' dapat diketahui mafsadat dari kloning manusia lebih banyak daripada maslahatnya. oleh karena itu, praktik kloning manusia bertentangan dengan hukum Islam dengan demikian kloning manusia dalam Islam hukumnya haram. Dalil-dalil keharamannya: Q.S. An-Najm: 45-46 yang artinya;

"45. Dan bahwasanya Dialah yang menciptakan berpasang-pasangan pria dan wanita. 46. Dari air mani, apabila dipancarkan."6

Di sini dinyatakan bahwa logika syari'at Islam dengan nash-nashnya yang mutlak, kaidah-kaidahnya yang menyeluruh, dan berbagai tujuan umumnya, melarang praktik kloning pada manusia. Karena jika kloning ini dilakukan pada manusia, maka akan mengakibatkan berbagai kerusakan sebagai berikut. 1. Hilangnya hukum variasi di alam raya. 2. Kerancuan hubungan antara orang yang di-kloning dengan orang hasil kloningnya. 3. Kemungkinan kerusakan lainnya seperti terjangkitnya penyakit. 4. Kloning bertentangan dengan sunnah untuk berpasang-pasangan.

\footnotetext{
${ }^{5}$ Q.S. Al-Baqoroh: ayat 29.

${ }^{6}$ Q.S. An-Najm: ayat 45-46.
}

Jurnal Pendidikan Agama Islam 
Menurut Fiqh Islam kloning pada tumbuhan dan hewan tidak terlarang dan tidak berdosa selagi menjaga supaya tidak terjadi kemadharatan.

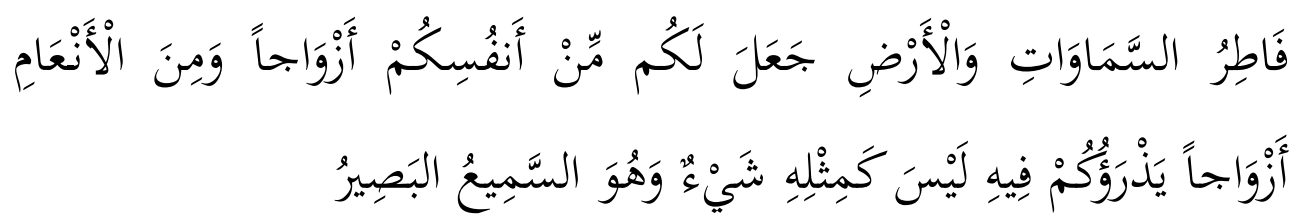

"(Allah) Pencipta langit dan bumi. Dia Menjadikan bagi kamu pasangan-pasangan dari jenis kamu sendiri, dan dari jenis hewan ternak pasangan-pasangan (juga). Dijadikan-Nya kamu berkembangbiak dengan jalan itu. Tidak ada sesuatu pun yang serupa dengan Dia. Dan Dia Yang Maha Mendengar, Maha Melihat."

Ulama Fiqih sepakat bahwa kloning dalam ruang lingkup manusia tidak boleh, dengan dalil-dalil sebagai berikut: 1. Al-Qur'an

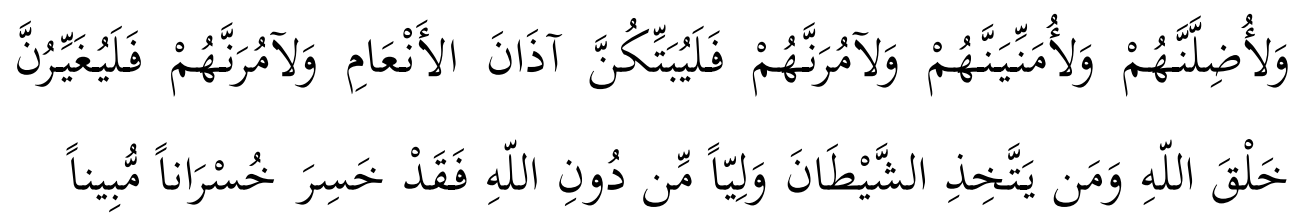

"Dan pasti akan kusesatkan mereka, dan akan kubangkitkan angan-angan kosong pada mereka dan akan kusuruh mereka memotong telinga-telinga binatang ternak, (lalu mereka benar-benar memotongnya), dan akan aku suruh mereka mengubah ciptaan Allah, (lalu mereka benar-benar mengubahnya). Barang siapa mnjadikan setan sebagai pelindung selain Allah, maka sungguh, dia menderita kerugian yang nyata."

Ayat di atas melarang kepada manusia untuk merubah ciptaan Allah Swt, barang siapa yang melakukan hal tersebut berarti dia telah mengikuti jalan syetan, dan sesungguhnya 
Al Qudus Nofiandri Eko Sucipto Dwijo

syetan itu selalu memerintah kepada kejelekan dan kemaksiatan.

Ada juga ayat Al-Qur'an yang menjelaskan tentang perintah Allah Swt kapada manusia untuk melaksanakan pernikahan dengan tujuan menghasilkan keturunan melalui hubungan antara suami istri.

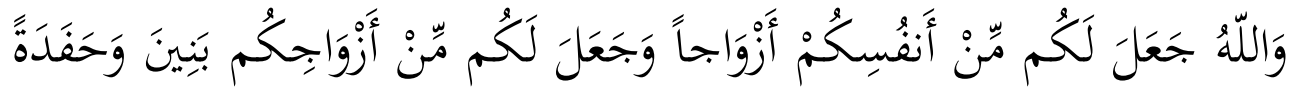

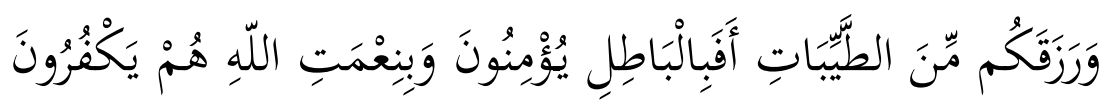

"Dan Allah menjadikan bagimu pasangan (suami atau istri) dari jenis kamu sendiri dan menjadikan anak dan cucu bagimu dar pasanganmu, serta memberimu rezeki dari yang baik. Mengapa mereka beriman kepada yang batil dan mengingkari nikmat Allah?"

2. Al-Hadits

$$
\text { وسلم : لا ضرر ولاضرار في الا سلا مب ( رواه الطبراني الله عنهما قال : قال رسو ل الله صلي الله عليه }
$$

3. Akal

Kloning manusia ada yang bersifat juz'i, yaitu mengganti bagian tubuh yang sudah tidak berfungsi dengan anggota tubuh orang lain yang sudah tidak terpakai, dengan syarat menjaga kemashlahatan manusia. Ada juga kloning yang bersifat kamil, yaitu membuat manusia dengan menggunakan teori seperti yang telah disebut diatas (tanpa malakukan hubungan suami istri). 
4. Qowaid Fiqhiyah

$$
\begin{aligned}
& \text { * رء المفا سد مقد م علي جلب المصا لح } \\
& \text { لاضر ر ولا ضرار } \\
& \text { الضر ر لا يزا ل بمثله }
\end{aligned}
$$

Inti dari penjelasan kaidah ini bahwa syariat itu menjaga kemashlahatan manusia, ketika ada suatu permasalahan pertentangan antara kemashlahatan dan kemadharatan dan ternyata kemadharatannya lebih besar maka yang harus didahulukan adalah mengambil kemashlahatan.

5. Fatwa Ulama tentang kloning:

a. Nashr Farid Wasil (mantan Mufti Negara Mesir) berkata: ulama telah sepakat bahwa kloning pada manusia tidak dibolehkan dari berbagai segi diantaranya; ilmiah, kedokteran, akhlak, syariat. Allah Swt telah memuliakan manusia dan telah menjadikannya sebagai khalifah di bumi. Firman Allah Swt;

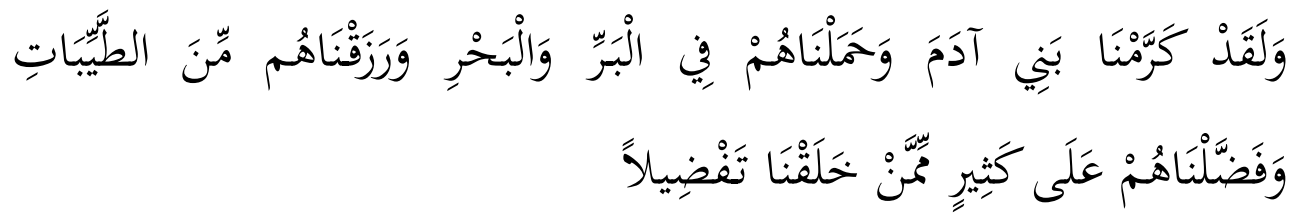

"Dan sungguh, Kami telah Memuliakan anak cucu Adam, dan Kami Angkut mereka di darat dan di laut, dan Kami Beri mereka rezeki dari yang baik-baik dan Kami lebihkan mereka di atas banyak makhluk yang Kami Ciptakan dengan kelebihan yang sempurna."7

b. Abdul Mu'thi Payumi -pengajar Aqidah Falsafah Universitas Al-Azhar- berkata: Sesungguhnya telah ada dalam Qaidah Syari'at:

${ }^{7}$ QS. Al-Isra: ayat 70. 
Al Qudus Nofiandri Eko Sucipto Dwijo

$$
\text { ان ما زا د ضرره علي نفعه فهو حرا م }
$$

c. Syekh Ibnu Utsaimin berpendapat bahwa kloning itu merupakan sebesar-besarnya kerusakan di bumi, dan serendah-rendahnya hukuman bagi yang melakukannya, yaitu potong tangan dan kaki secara silang (tangan kanan dan kaki kiri) dan apabila melakukan lagi tangan kiri dan kaki kanan.

Hal yang perlu diketahui oleh umat manusia, bahwa Allah Swt menurunkan syariat Islam dengan tujuan yang disebut dengan (Maqasid As-Syariah), yaitu untuk menjaga kemashlahatan, bukan untuk menimbulkan kemadharatan terhadap diri manusia.

Dalam Ilmu Ushul Fiqh terdapat istilah Mashlahah alMursalah yang berarti mengambil suatu kemashlahatan/ kebaikan dan meninggalkan suatu kemadharatan/ bahaya, atau dalam arti lain, suatu kemashlahatan yang tidak disinggung oleh syara' dan tidak pula terdapat dalil-dalil yang menyuruh untuk mengerjakan atau meninggalkannya, sedangkan jika dikerjakan akan mendatangkan kebaikan yang besar atau kemaslahatan.

Kalau dilihat Imam-imam Madzhab dalam menggali hukum terhadap suatu permasalahan mereka sangat mementingkan kemashlahatan manusia dan tidak mempersulitnya, terlebih Imam Malik yang dikenal banyak mengambil maslahah dalam pengambilan hukumnya. Begitu juga Imam Ahmad bin Hanbal, Imam Asy-Syathibi, Imam Ibnu Qayyim Al-Jauzi, dan lain-lain. ${ }^{8}$

\footnotetext{
${ }^{8}$ Ujang Romi, "Kloning dalam Perspektif Islam", dalam https://www.facebook. com/permalink. php?story fbid $=366254210146826 \& i d=151125391659710$ (Akses pada 14 Oktober 2014).

Jurnal Pendidikan Agama Islam Volume 02 Nomor 02 November 2014 Hal $342-356$
} 
Kloning dapat berlangsung melalui proses pengambilan sel dari tubuh manusia, baik laki-laki ataupun perempuan, kemudian inti selnya diambil dan digabungkan dengan sel telur perempuan yang telah dibuang inti selnya. Sel telur ini lalu ditransfer ke dalam rahim perempuan agar memperbanyak diri, berkembang, berubah menjadi janin dan akhirnya dilahirkan sebagai bayi. Bayi yang dilahirkan merupakan keturunan dengan kode genetik yang sama dengan manusia yang menjadi sumber pengambilan sel tersebut.

Melihat fakta kloning manusia secara menyeluruh, syari'at Islam mengharamkan kloning terhadap manusia dengan beberapa argumentasi. Pertama, anak-anak produk proses kloning dihasilkan melalui cara yang tidak alami (percampuran antara sel sperma dan sel telur). Padahal, cara alami inilah yang telah ditetapkan oleh syariat sebagai sunnatullah menghasilkan anak-anak dan keturunannya. Allah Swt berfirman;

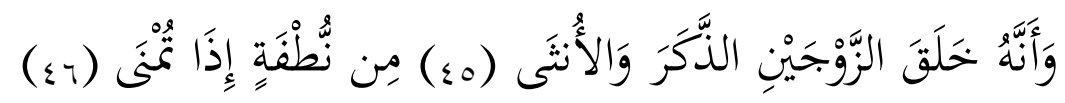

"Dan bahwasannya Dialah yang menciptakan berpasangpasangan laki-laki dan perempuan dari air mani apabila dipancarkan."9

Dalam ayat lain dinyatakan;

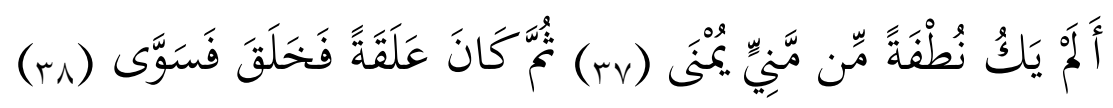

"Bukankah dia dahulu setetes mani yag ditumpahkan (ke dalam rahim), kemudian mani itu menjadi segumpal darah, lalu Allah menciptakannya dan menyempur-

${ }^{9}$ QS. an-Najm, 53: ayat 45-46. 
Al Qudus Nofiandri Eko Sucipto Dwijo

nakannya. Lalu Allah menjadikan daripadanya sepasang laki-laki dan perempuan."10

Kedua, anak-anak produk kloning dari perempuan tanpa adanya laki-laki - tidak akan memunyai ayah. Anak produk kloning tersebut jika dihasilkan dari proses pemindahan sel telur - yang telah digabungkan dengan inti sel tubuh - ke dalam rahim perempuan yang bukan pemilik sel telur, tidak pula akan mempunyai ibu sebab rahim perempuan yang menjadi tempat pemindahan sel telur tersebut hanya menjadi penampung (mediator). Oleh karena itu, kondisi ini sesungguhnya telah bertentangan dengan firman Allah Swt.;

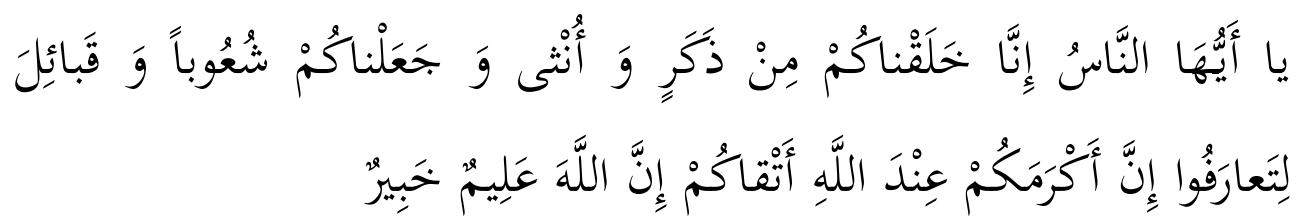

"Hai manusia, sesungguhnya kami menciptakan kamu dari seorang laki-laki dan seorang perempuan dan menjadikan kamu berbangsa - bangsa dan bersuku-suku supaya kamu saling kenal-mengenal. Sesungguhnya orang yang paling mulia diantara kamu di sisi Allah ialah orang yang paling taqwa diantara kamu. Sesungguhnya Allah Maha mengetahui lagi Maha Mengenal."11

Hal itu juga bertentangan dengan firman Allah Swt.;

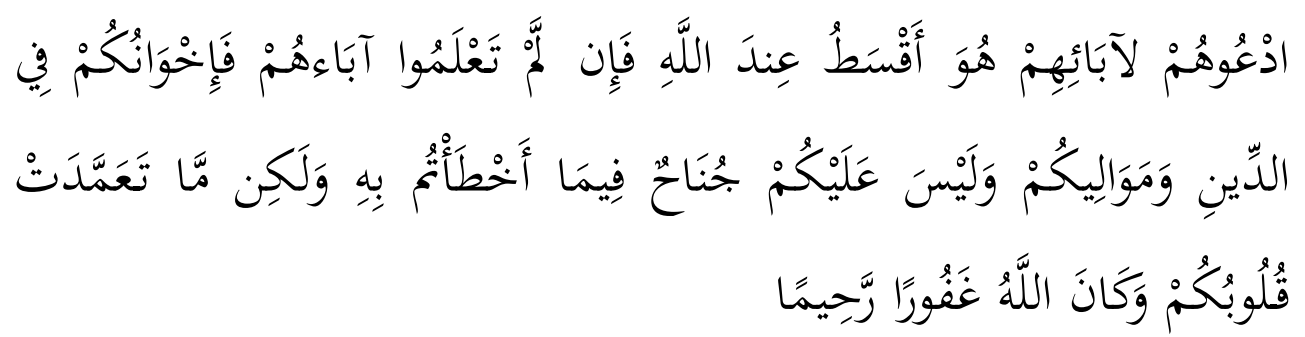

\footnotetext{
${ }^{10}$ QS. al-Qiyâmah, 75: ayat 37-38.

${ }^{11}$ QS al-Hujurât, ayat 49: 13.
}

Jurnal Pendidikan Agama Islam

Volume 02 Nomor 02 November 2014

Hal $344-356$ 
"Panggillah mereka (anak-anak angkat itu) dengan (memakai) nama bapak-bapak mereka; Itulah yang lebih adil pada sisi Allah, dan jika kamu tidak mengetahui bapak-bapak mereka, maka (panggillah mereka sebagai) saudara-saudaramu seagama dan maula-maulamu ${ }^{12}$, dan tidak ada dosa atasmu terhadap apa yang kamu khilaf padanya, tetapi (yang ada dosanya) apa yang disengaja oleh hatimu. Dan adalah Allah Maha Pengampun lagi Maha Penyayang."13

Ketiga, kloning manusia akan menghilangkan nasab (garis keturunan). Padahal Islam telah mewajibkan pemeliharaan nasab. Ini berdasarkan hadits yang diriwayatkan dari Ibnu Abbas r.a. yang mengatakan bahwa Rasulullah Saw. telah bersabda;

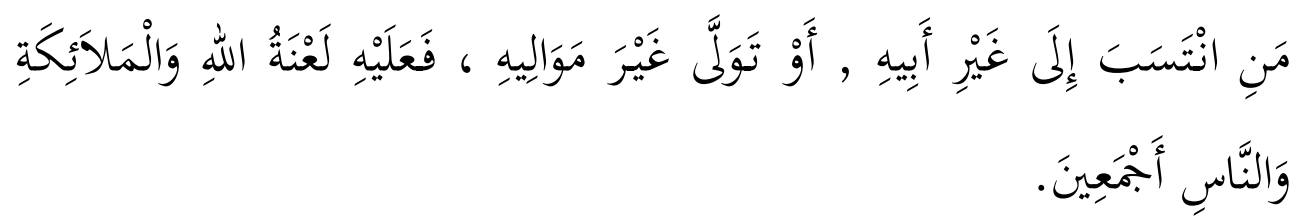

"Siapa saja yang menghubungkan nasab kepada orang yang bukan ayahnya, atau (seorang budak) bertuan (loyal/taat) kepada selain tuannya, maka dia akan mendapat laknat dari Allah, para malaikat dan seluruh manusia."14

Diriwayatkan juga dari Abu 'Utsman an-Nahdi ra., yang berkata;

\footnotetext{
12 Maula-maula ialah: seorang hamba sahaya yang sudah dimerdekakan atau seorang yang telah dijadikan anak angkat, seperti Salim anak angkat Huzaifah, dipanggil maula Huzaifah, ${ }^{13}$ QS. al-Ahzâb: ayat 33: 5.

${ }^{14}$ Hadis Riwayat Ibnu Majah, Ahmad, Ibnu Hibban, Al-Bazzar, Abu Ya'la dan Ath-Thabrani dari Ibnu Abbas.
} 
Al Qudus Nofiandri Eko Sucipto Dwijo

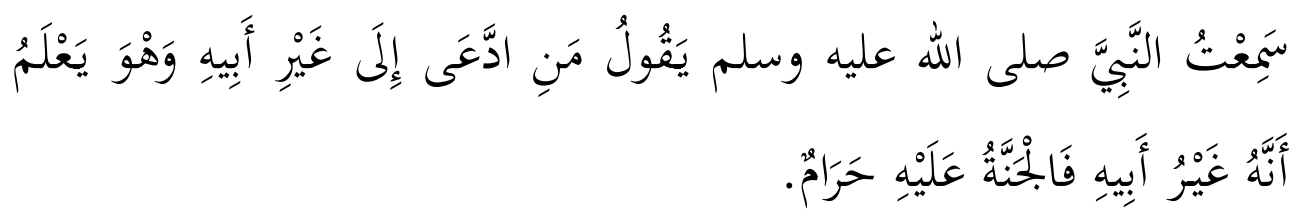

"Aku mendengar Sa'ad dan Abu Bakrah masing-masing berkata, 'Kedua telingaku telah mendengar dan hatiku telah menghayati sabda Muhammad saw., "Siapa saja yang mengaku-ngaku (sebagai anak) kepada orang yang bukan bapaknya, padahal dia tahu bahwa orang itu bukan bapaknya, maka surga baginya haram."15

Diriwayatkan juga dari Abu Hurairah ra., bahwasannya tatkala turun ayat li'an dia mendengar Rasulullah Saw. Bersabda;

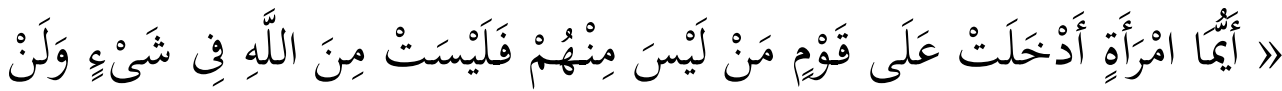

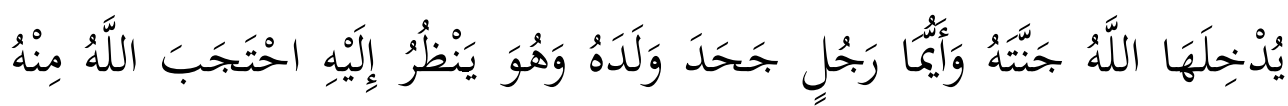

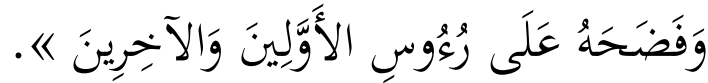

"Siapa saja perempuan yang memasukkan kepada suatu kaum nasab (seseorang) yang bukan dari kalangan kaum itu, maka dia tidak akan mendapat apapun dari Allah dan Allah tidak akan pernah memasukkannya ke dalam surga. Dan siapa saja laki-laki yang mengingkari anaknya sendiri padahal dia melihat kemiripannya, maka Allah akan akan tertutup darinya dan Allah akan membeberkan perbuatannya itu dihadapan orang-orang yang terdahulu dan kemudian (pada Hari Kiamat)."16

\footnotetext{
${ }^{15}$ Hadis Riwayat Al-Bukhari, Muslim, Abu Dawud, Ibnu Majah, Ahmad, Ibnu Hibban, Al-Bazzar, Ath-Thayalisi, Abu Ya'la, Al-Baihaqi dan Ibnu Khuzaimah.

${ }^{16}$ Hadits Riwayat Abu Dawud, An-Nasa'i, Ibnu Hibban, Al-Baihaqi, Al-Hakim dan Ad-Darimi.
}

Jurnal Pendidikan Agama Islam

Volume 02 Nomor 02 November 2014

Hal $346-356$ 
Kloning manusia yang bermotif memproduksi manusiamanusia unggul dalam hal kecerdasan, kekuatan fisik, kesehatan, kerupawanan; jelas mengharuskan seleksi terhadap orang-orang yang akan dikloning, tanpa memperhatikan apakah mereka suami-istri atau bukan, sudah menikah atau belum. Sel-sel tubuh itu akan diambil dari perempuan atau lakilaki yang terpilih. Semua ini akan mengacaukan, menghilangkan dan membuat bercampur aduknya nasab (garis keturunan).

Keempat, memproduksi anak melalui proses kloning akan mengacaukan pelaksanaan hukum-hukum syara' seperti hukum tentang perkawinan, nasab, nafkah, hak dan kewajiban antara bapak dan anak, waris, perawatan anak, hubungan kemahraman, hubungan 'ashabah, dan banyak lagi. Di samping itu, kloning akan mencampuradukkan dan menghilangkan nasab serta menyalahi fitrah yang telah diciptakan Allah Swt untuk manusia dalam masalah kelahiran anak. Konsekuensi kloning ini akan menjungkirbalikkan struktur kehidupan masyarakat. ${ }^{17}$

Pengharaman ini hanya berlaku untuk kasus kloning pada manusia saja. Kloning bagi hewan dan tumbuhan, apalagi jika bertujuan untuk mencari obat, justru dibolehkan bahkan disunnahkan. Ini dapat dilihat dari dua hadits di bawah ini;

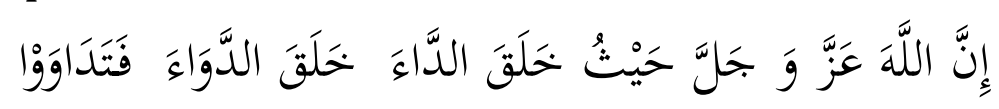

"Sesungguhnya Allah 'Azza Wa Jalla setiap kali menciptakan penyakit, Dia menciptakan pula obatnya. Maka berobatlah kalian!."18

17 http://muhsinhar.staff.umy.ac.id/kontroversi-tentang-kloning-manusiadalam-perspektif-hukum-islam-2/ (Akses 14 Oktober 2014).

${ }^{18}$ Hadits Riwayat Imam Ahmad. 
Imam Abu Dawud dan Ibnu Majah meriwayatkan dari Usamah bin Syuraik ra., yang berkata;

$$
\begin{aligned}
& \text { أَتَيْتُ النَّبَّ -صلى الله عليه وسلمَ- فَجَاءَ الأَعْرَابُ ِِنْ هَا هُنَا وَهَا هُنَا, }
\end{aligned}
$$

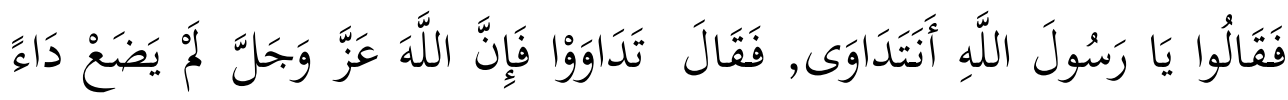

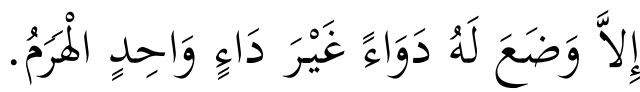

"Aku pernah bersama Nabi Saw., lalu datanglah orangorang Arab Badui dari beberapa penjuru. Mereka berkata: 'Wahai Rasulullah, bolehkah kami berobat?' Maka Nabi Saw. menjawab, "Ya. Hai hamba-hamba Allah, berobatlah kalian sebab sesungguhnya Allah Azza wa Jalla tidaklah menciptakan penyakit kecuali menciptakan pula obat baginya, selain satu penyakit, yaitu "pikun."

Berdasarkan dalil di atas diperbolehkan memanfaatkan proses kloning untuk memperbaiki kualitas tanaman dan hewan untuk mempertinggi produktivitasnya dengan pertimbangan fath adz-dzarâi' (li jalb al-mashâlih) dan tidak diperbolehkan untuk manusia, dengan pertimbangan sadd adzdzarâi' (li dar' al-mafâsid). ${ }^{19}$

\section{Penegasan Argumen Larangan Kloning Manusia}

Berkaitan dengan penciptaan manusia, al-Qur'an menyatakan bahwa manusia diciptakan sebagai makhluk paling sempurna di antara seluruh makhluk yang ada di alam semesta. Hal itu secara tegas dinyatakan Allah Swt dalam surat

19 Denny Kodrat. Peneliti Institute of Islamic Analysis and Development (INQIYAD) Bandung, dalam: http://www.pikiran-rakyat.com/cetak/0103/ 13/0803.htm); lihat juga dalam http://muhsinhar.staff.umy.ac.id/kontroversitentang-kloning-manusia-dalam-perspektif-hukum-islam-2/ (Akses 14 Oktober 2014).

Jurnal Pendidikan Agama Islam

Volume 02 Nomor 02 November 2014

Hal $348-356$ 
at-Tin ayat 4 yang artinya: "Sesungguhnya Kami telah menciptakan manusia dalam bentuk yang sebaik-baiknya."

Penjelasan Allah Swt dalam al-Qur'an tentang kesempurnaan penciptaan manusia di antara segala makhluk ciptaan-Nya yang lain, tentu tidak dapat dibantah oleh orangorang beriman. Dengan menggunakan logika sederhana dapat digeneralisasi bahwa sesuatu yang sudah sempurna, kemudian disempuranakan lagi, tentu saja dapat menghilangkan sifat kesempurnaannya, bahkan bisa berakibat rusak sama sekali.

Penciptaan manusia dalam al-Qur'an disebutkan pada beberapa ayat yang secara jelas menggambarkan prosesnya dimulai dari pembuahan sel telur oleh sperma, kemudian menjadi segumpal darah (fetus) yang tumbuh dalam rahim dan seterusnya sampai lahir .

"Sesungguhnya Kami telah menciptakan manusia dari setetes mani yang bercampur yang Kami hendak mengujinya (dengan perintah dan larangan), karena itu Kami jadikan dia mendengar dan melihat."20

Jadi pertemuan antara sperma dengan sel telur merupakan syarat bagi tencapainya hasil yang sempurna. Selain dengan cara tersebut Allah Swt tidak memberikan jaminan bagi produk yang dihasilkan.

"Maka hadapkanlah wajahmu dengan lurus kepada agama Allah; (tetaplah atas) fitrah Allah yang telah menciptakan manusia menurut fitrah itu. Tidak ada peubahan pada fitrah Allah. (Itulah) agama yang lurus; tetapi kebanyakan manusia tidak mengetahui."21

Seorang anak merupakan hasil kontribusi antara sperma dan sel telur, dimana masing-masing komponen membawa

${ }^{20}$ QS. Al-Insaan: ayat 2.

${ }^{21}$ QS. Ar-Ruum: ayat 30. 
substansi yang berbeda sehingga hanya dari keduanya bisa lahir seorang bayi yang sempurna, dalam arti semua komponen tubuhnya berfungsi dengan normal. Sampai saat ini pembuahan secara konvensional telah terbukti kesempurnaannya. Kalaupun ada bayi yang lahir dalam keadaan cacat, penyebabnya bukan karena kesalahan metodenya.

Metode kloning berbeda dengan metode pembuahan biasa dalam satu hal, yaitu sel telur tidak memerlukan sperma lagi untuk pembuahannya. Pada prinsipnya bayi kloning dibuat dengan mempersiapkan sel telur yang sudah diambil intinya kemudian di "fusi" dengan sel donor, yang merupakan sel dewasa dari suatu organ tubuh. Fusi tadi kemudian ditanamkan ke rahim dan dibiarkan berkembang dalam rahim sampai lahir. Banyak ahli genetik yang skeptis dengan keberhasilan manusia kloning. Dikatakan bahwa bisa jadi hasil "kloning" merupakan mahluk hidup yang sama sekali berlainan dari induknya. Para politikus juga masih pro dan kontra dalam memberikan ijin bagi penelitinya di bidang ini.

Bayi yang lahir dari metode kloning, memiliki banyak sekali kelemahannya. Hal ini telah dibuktikan secara ilmiah pada berbagai kasus. Sebagai contoh domba Dolly ternyata lahir setelah melalui experimen sebanyak 272 kali, dengan kelebihan berat badan, jantung yang lebih besar dan juga organ-organ lainnya. Tikus-tikus Hawai yang kelihatannya mirip induknya ternyata menunjukkan proses penuaan yang lebih cepat dibanding tikus hasil reproduksi normal.

Test genetik membuktikan terdapatnya mutasi dengan frekuensi yang sangat tinggi pada gen-gen hewan produk kloning. Efeknya baru akan terlihat setelah hewan hidup beberapa lama. Dengan demikian apabila seorang manusia dewasa menginginkan anaknya lahir dengan cara "kloning", 
bisa dikatakan dia seorang manusia yang kejam, karena sudah merancang anaknya sendiri untuk menderita cacat baik secara fisik maupun psikologis selama hidupnya.

Terlepas dari alasan-alasan ilmiah, seorang muslim hendaknya mempunyai pendapatnya sendiri berdasarkan agama untuk ikut menyetujui ataupun menolak kemajuan ilmu ini. Di dalam Islam, kelangsungan hidup manusia dilestarikan secara sunnatullah melalui pembentukan keluarga yang disahkan oleh syariat Islam. Selanjutnya dari pasangan suami istri dilahirkan anak-anak yang merupakan amanah dari Allah Swt. Sesuai dengan Firman Allah Swt. dalam surat AdzDzariyaat ayat 49 , yang artinya:

"Dan segala sesuatu kami ciptakan berpasang-pasangan supaya kamu mengingat kebesaran Allah."22

Dengan metode kloning kelahiran seorang bayi tidak lagi memerlukan sperma ayah. Seorang ibu sudah cukup secara teoritis untuk punya anak. Sedangkan seorang laki-laki, apabila ingin punya anak tidak perlu istri. Cukup hanya memesan sel telur pada suatu firma, memberikan selnya dari salah satu organnya dan kemudian menitip calon anaknya pada suatu rahim wanita, yang bisa jadi juga telah disediakan oleh firma tersebut. Firma seperti itu bukan khayalan, tapi sudah berdiri di Amerika, salah satunya adalah Clonaid.

Dari cerita ini bisa dibayangkan bahwa lembaga perkawinan akan semakin tidak dihargai dan pembentukan keluarga tidak mempunyai arti lagi bagi manusia. Padahal keluarga dibentuk tidak hanya untuk memproduksi anak, akan tetapi juga untuk memberikan perlindungan psikologis terhadap anggota- anggotanya serta yang paling utama adalah dalam rangka ibadah.

${ }^{22}$ QS. Adz-Dzariyaat: ayat 49 
Al Qudus Nofiandri Eko Sucipto Dwijo

"Dan di antara tanda-tanda kekuasaan-Nya ialah dia menciptakan untukmu istri-istri dari jenismu sendiri, supaya kamu cenderung dan merasa tenteram kepadanya, dan dijadikan-Nya diantaramu rasa kasih dan sayang. Sesungguhnya pada yang demikian itu benarbenar terdapat tanda-tanda bagi kaum yang berfikir."23

Majma' Buhuts Islamiyyah Al-Azhar di Kairo mengeluarkan fatwa yang menyatakan bahwa kloning manusia itu haram dan harus diperangi serta dihalang-halangi dengan berbagai cara. Naskah fatwa itu juga menguatkan bahwa kloning manusia telah menjadikan manusia yang dimuliakan Allah Swt menjadi objek penelitian dalam percobaan, serta melahirkan berbagai masalah pelik lainnya. Fatwa tersebut juga mensinyalir bahwa Islam tidak menentang ilmu pengetahuan yang bermanfaat, bahkan sebaliknya, Islam justru mendukung bahkan memuliakan para ilmuwan. Namun, bila ilmu pengetahuan itu membahayakan serta tidak mengandung manfaat, maka Islam mengharamkan dengan melindungi diri dari bahaya tersebut.

"Dan Sesungguhnya telah Kami muliakan anak-anak Adam, Kami angkut mereka di daratan dan di lautan, Kami beri mereka rezki dari yang baik-baik dan Kami lebihkan mereka dengan kelebihan yang sempurna atas kebanyakan makhluk yang telah Kami ciptakan". (QS. AlIsra: 70).

Demi menetapkan ketegasan hukum Kloning, para ulama kentemporer menggunakan ijtihad insya'i, karena persoalan tersebut belum dibahas dalam kitab-kitab fiqh klasik.

${ }^{23}$ QS. Ar-Ruum: ayat 21.

Jurnal Pendidikan Agama Islam

Volume 02 Nomor 02 November 2014

Hal $352-356$ 
1. Ditinjau dari sisi hifzh al-din (memelihara agama), kloning manusia tidak membawa dampak negatif terhadap keberadaan agama.

2. Ditinjau dari sisi hifzh al-nafs (memelihara jiwa), kloning tidak menghilangkan jiwa bahkan justru melahirkan jiwa yang baru.

3. Dilihat dari sisi hifzh al-'aql (memelihara akal), kloning juga tidak mengancam eksistensi akal, bahkan keberhasilan Kloning yang sempurna dapat membuat manusia mempunyai akal cerdas.

4. Jika dilihat dari sisi hifzh al-nasl (memelihara keturunan), kloning manusia dipertanyakan. Dalam pandangan Islam, masalah keturunan merupakan sesuatu yang sangat essensial, karena keturunan mempunyai hubungan erat dengan hukum yang lain seperti pernikahan, warisan, muhrim, dan sebagainya.

5. Apabila ditinjau dari sisi hifzh al-mal (memelihara harta), akan terkait dengan mashlahat dan mafsadat yang diperoleh dari usaha pengkloningan. Andaikata Kloning terhadap manusia hanya akan menghambur-hamburkan harta, tanpa adanya keseimbangan dengan manfaat yang diperoleh, maka kloning menjadi terlarang.

Dari aspek agama, penerapan kloning memang tidak disinggung secara eksplisit dan spesifik. Cloning was not anticipated the extant holy books of the various religions (persoalan kloning tidak diantisipasi dalam berbagai kitab suci agama-agama yang ada). ${ }^{24}$ Pada tanggal 28 Juni-3 Juli 1997, para ulama mengadakan seminar dengan tema "Islamic Fiqh Academy" di Makkah al-Mukarramah dengan agenda utama

24 Muhammad Ali, "Kloning Manusia dan Posisi Agama-Agama", Kompas (Jakarta, 27 Oktober 2001). 
melihat posisi kloning dalam syariat Islam. Peserta seminar itu sebanyak 125 orang terdiri dari para Fuqaha dan ahli biotek dari berbagai penjuru dunia. Secara aklamasi mereka memutuskan bahwa kloning terhadap hewan dan tumbuhan diperbolehkan, sedangkan kloning terhadap manusia diharamkan. ${ }^{25}$

Dengan penerapan kloning, kemapanan dan keluhuran cita-cita sebuah perkawinan dalam Islam akan terusik. Boleh jadi, di masa yang akan datang manusia tidak membutuhkan perkawinan untuk mendapatkan keturunan. Seks hanya diperlukan untuk melampiaskan hawa nafsu birahi terhadap lawan jenis tanpa mempertimbangkan akibat dan tanggung jawab dari hubungan seksualitas tersebut.

Secara hukum-syari'ah, Islam sangat memperhatikan hubungan nasab dan famili, karena berkait dengan urusan yang lebih jauh. Seperti masalah hukum mahram tidaknya seseorang dengan lawan jenisnya. Masalah warisan, wali nikah bagi seorang wanita, konsep saudara persusuan, nafkah dan kehidupan serta laqab. Seorang anak yang dilahirkan dari proses perkawinan yang sah memiliki kejelasan tentang hal-hal diatas, namun seorang anak dari hasil kloning tidak memilikinya sehingga akan terjadi kerancauan dari segi syariahnya.

Latar belakang keluarga dari garis keturunan ibu dan bapak masih tetap menjadi unsur penting di dalam berbagai pertimbangan hukum. Jika seseorang tidak mempunyai ayah atau ibu konvensional belum ada contoh pemecahannya dalam hukum atau fikih Islam. Berbeda kalau seseorang kehilangan ayah atau ibu karena meninggal dunia atau hilang, dapat segera diselesaikan oleh pengadilan.

\footnotetext{
${ }^{25}$ The 1997 Meeting: "Islamic Fiqh Academy", dalam http://www.jamiat.org.za/ c.facademy.html. (Akses pada 14 Oktober 2014).
}

Jurnal Pendidikan Agama Islam 


\section{Penutup}

Ketika ditinjau dari sisi hifzh al-din (memelihara agama), kloning manusia tidak membawa dampak negatif terhadap keberadaan agama. Ditinjau dari sisi hifzh al-nafs (memelihara jiwa), kloning tidak menghilangkan jiwa bahkan justru melahirkan jiwa yang baru. Dilihat dari sisi hifzh al'aql (memelihara akal), kloning juga tidak mengancam eksistensi akal, bahkan keberhasilan Kloning yang sempurna dapat membuat manusia mempunyai akal cerdas.

Jika dilihat dari sisi hifzh al-nasl (memelihara keturunan), kloning manusia dipertanyakan. Dalam pandangan Islam, masalah keturunan merupakan sesuatu yang sangat essensial, karena keturunan mempunyai hubungan erat dengan hukum yang lain seperti pernikahan, warisan, muhrim, dan sebagainya. Apabila ditinjau dari sisi hifzh al-mal (memelihara harta), akan terkait dengan mashlahat dan mafsadat yang diperoleh dari usaha pengkloningan. Andaikata Kloning terhadap manusia hanya akan menghambur-hamburkan harta, tanpa adanya keseimbangan dengan manfaat yang diperoleh, maka kloning menjadi terlarang.

Dengan penerapan kloning, kemapanan dan keluhuran cita-cita sebuah perkawinan dalam Islam akan terusik. Boleh jadi, di masa yang akan datang manusia tidak membutuhkan perkawinan untuk mendapatkan keturunan. Seks hanya diperlukan untuk melampiaskan hawa nafsu birahi terhadap lawan jenis tanpa mempertimbangkan akibat dan tanggung jawab dari hubungan seksualitas tersebut. Dengan demikian, kemafsadatan yang ditimbulkan akibat kloning manusia lebih besar daripada kemanfataannya. Oleh karena itu, kloning manusia diharamkan dalam ajaran Islam. 
Al Qudus Nofiandri Eko Sucipto Dwijo

\section{DAFTAR PUSTAKA}

Al-Quran al-Karim

Al-Hadits al-Nabawy

Ali, Muhammad, 2001, "Kloning Manusia dan Posisi AgamaAgama", Kompas (Jakarta, 27 Oktober).

Denny Kodrat. Peneliti Institute of Islamic Analysis and Development (INQIYAD) Bandung, dalam: http://www. pikiran-rakyat.com/ cetak/0103/ 13/0803.htm)

http://muhsinhar.staff.umy.ac.id/kontroversi-tentang-kloning-manusia-dalamperspektif-hukum-islam-2/ (Akses 14 Oktober 2014).

http://abraham4544.wordpress.com/umum/hukum-kloning-dalamperspektif-agama-islam/ (Akses pada 15 Oktober 2014).

http://fun-bio.blogspot.com/2011/04/kloning-manusia-dalam-perspektifislam.html (Akses pada 15 Oktober 2014).

http://muhsinhar.staff.umy.ac.id/kontroversi-tentang-kloning-manusia-dalamperspektif-hukum-islam-2/ (Akses 14 Oktober 2014).

https://www.facebook.com/permalink. php?story fbid=366254210146826 \&id=151125391659710 (Akses pada 14 Oktober 2014).

Musbikin, Imam , 2001, Qowa'id al-Fiqhiyah (Jakarta: Raja Grafindo Persada).

The 1997 Meeting: "Islamic Fiqh Academy", dalam http://www. jamiat.org.za/c.facademy.html. (Akses pada 14 Oktober 2014).

Umar, Nasaruddin, 2002, "Pandangan Islam terhadap Kolning Manusia", Kompas (Jakarta: 21 April).

Ujang Romi, "Kloning dalam Perspektif Islam", dalam https://www. facebook.com/permalink. php?story fbid $=3662542 \quad 10146826 \&$ id $=$ $\underline{151125391659710}$ (Akses pada 14 Oktober 2014).

Jurnal Pendidikan Agama Islam

Volume 02 Nomor 02 November 2014

Hal $356-356$ 